\title{
Reimagining public science education: the role of lifelong free-choice learning
}

\author{
John H. Falk ${ }^{*}$ (D) and Lynn D. Dierking
}

\begin{abstract}
Profound changes are occurring in society, disrupting current systems and institutions; these disruptions also are affecting science education practice and research. Science learning is becoming a lifelong, self-directed process, dominated by out-of-school, free-choice learning experiences. By necessity these disruptions in the science learning narrative necessitate that societies rethink what constitutes public science education in the twenty-first century. Rather than focusing only on schooling and university/post-secondary training, public science education should include meeting the lifelong science learning needs of all people, at all stages of life, wherever a person is, whenever she faces a learning need. In this context, public science education must be learner-centered and equitable, serving the real lifelong needs, realities and motivations of all people, not just those of children and youth or the most privileged. Such a comprehensive approach to public science education does not currently exist. The key to enacting such a comprehensive approach requires thinking outside of the current educational box, moving beyond Industrial-Age top-down, one-size-fits-all command and control approaches that center on schooling and higher education. A reimagined approach to public science education would embrace more distributed, synergistic, personalized, just-in-time approaches that emphasize and reward lifelong learning, including learning beyond school. This article discusses the scope and scale of free-choice public science learning across a range of informal contexts - museums, zoos and aquariums; broadcast media such as television and radio; hobby groups; electronic media such as social networks, educational games, podcasts and the Internet. In addition, the paper considers the challenges faced by both practitioners and researchers attempting to promote and reform science education in more systemic and comprehensive ways. As the what, where, when, how and with whom of science learning continues to evolve, new educational practices and research approaches will be required; approaches that place the individual and her lifelong, free-choice learning at the center, rather than the periphery of the public's lifelong science education.
\end{abstract}

Keywords: Lifelong learning, Free-choice learning, Informal, Self-directed learning

\section{Introduction}

Profound changes are occurring in society, disrupting current systems and institutions; these disruptions are also affecting science education practice and research. Just as the information revolution dramatically transformed the world, this "quiet" learning revolution is changing the way people live and interact in the twenty-first century. Learning today is $24 / 7$, continuous and on demand. Whether 5 years old or 95, learners seek educational experiences from a myriad of sources.

\footnotetext{
* Correspondence: john.falk@freechoicelearning.org

Institute for Learning Innovation, Oregon State University, 8100 NW Ridgewood Drive, Corvallis, OR 97330, USA
}

To create a comprehensive lifelong science education system, societies must recognize, respect and support the various places, ways and reasons why people of all ages learn and engage in science across their lifetime-in school, certainly, but also at work, in the home, and in everyday life. As science learning professionals, we need to be seeking new ways to engage science learners of all ages in co-constructing their own learning of science, whether disciplinary or interdisciplinary. This is an enormous, long-term undertaking, requiring careful thought, collaboration across settings, deliberation and much formative testing; much of which is beyond the purview of this article. We focus on the piece of this lifelong science learning system that we know best: the critical role that 
free-choice (also sometimes referred to as informal) science learning plays in such a comprehensive, whole life approach to science education.

\section{Scope \& scale of free-choice public science education}

Today's learners engage in science learning every day across their lives-at home and while in the community. Adults spend $95+\%$ of their life learning while at work or while pursuing leisure activities, and even children spend only $20 \%$ of their time in school (Falk \& Dierking, 2010). The educational arena of the twenty-first century is increasingly a mix of schools and universities, digital media providers, businesses and a nation's vast network of informal educational institutions and resources: national parks, libraries, public health and environmental organizations, museums, youth- and adult-serving organizations (Archer, Dawson, DeWitt, Seakins, \& Wong, 2015; Falk et al., 2015; National Research Council, 2009, 2015).

Collectively, these resources form a complex ecosystem of science learning resources and opportunities (cf., Falk et al., 2015; National Research Council, 2015). This ecosystem of intersecting educational entities should not be thought of as merely a "backdrop" for science learning, but rather as the dynamic learning context which determines how people engage, interact and make sense of the sciencerelated topics and challenges they encounter in their daily lives (Barab \& Kirshner, 2001); a learning ecosystem where a growing number of individuals, both children and adults, can customize and take charge of their own learning.

Several recent studies reinforce this reality. For example, results from a major international investigation of a sample of approximately 12,000, conducted in 17 communities in 13 European, Australasian, North American and South American countries found that both adults and youth who utilized science centers, were significantly more likely than adults and youth who did not, to have greater science understanding, interest, identity and engagement (Falk et al., 2016; Shein, Falk, \& Li, 2019), independent of income, education and even prior interest.

In a more recent study of the role of science rich resources (schooling, higher education, workplace and informal resources) on the public's science interest, a random sampling of 3001 adults and 1762 youth from three major U.S. cities - Los Angeles, Philadelphia and Phoenix - revealed that both short- and long-term interest in science was primarily attributable to free-choice learning experiences, including visiting science centers, reading science-related books, watching science-related television shows and using the Internet to learn about science (cf., Falk, Meier, Pattison, Livingston, \& Bibas, 2019; Falk, Pattison, Meier, Livingston, \& Bibas, 2018). Although both youth and adults indicated that they had quality science experiences both in and outside of school when they were young, only the quality early science experiences outside of school emerged as significant predictors of both adults' and youth's long-term science interest. Both of these studies investigated science learning broadly, across a wide range of disciplines. It is not an exaggeration to say, that a great deal of public science understanding and engagement occurs across the lifespan, much of it beyond school (this includes schoolaged children, particularly those in the primary grades in the US, in which little, if any, science is taught). Given this increasing reality, how best to study the role of freechoice learning in public understanding and participation in science? Although there are an increasing number of individuals, ourselves included, who have begun trying to think about this question much more systematically and systemically, the vast proportion of research in free-choice learning has been more granular and nonsystemic.

\section{Free-choice science learning research}

Paralleling the growing awareness of the importance of lifelong out-of-school science learning, is an exponential expansion in the quantity of science learning research being conducted in these settings. Historically, the field suffered from a paucity of research, often scattered across many disciplines and sub-disciplines, with few efforts to consolidate, situate and synthesize it within an overall framework. However, there is a growing body of research investigating science learning in and from a wide variety of non-school environments, both physical and virtual. Much of this research is still focused exclusively on children, but there is growing awareness that also investigating adult learning is critical to comprehensively understanding lifelong science learning. Several recent U.S.-funded national studies provide a strong foundation for this research (cf., National Research Council, 2009, 2011, 2015, 2016, 2017), with data coming from studies of physics, chemistry, life science, geosciences and the social sciences, as well as across disciplines.

The collective work on learning in and from museumlike settings represents the most coherent body of this research, but studies also have been conducted in varied contexts including community, health and home settings (cf., Archer et al., 2015; Diaz et al., 2002; NRC, 2009, 2015; Vedder-Weiss, 2016). Investigations in museums often focus on why the public visits science-oriented museums, and what and how these visitors learn from visiting them. The public seems to use these settings to fulfil one of several basic learning needs, such as: a) support their own curiosity and interest in science; b) support the learning needs of others, e.g., children or partners; c) build personal identity, either personally or professionally; d) refresh and rejuvenate themselves; 
and/or e) satisfy a sense of exploration, a desire to see and do novel things (Falk, 2009, 2018; Phelan, Bauer, \& Lewalter, 2018; Sheng \& Chen, 2012). These needs often are designed to learn specific science information, but just as frequently the learner's goals are tangential to specific science learnings.

Research has shown that rather than focusing primarily on what they expect to see or do not know, museum visitors disproportionately are attracted to what they "sort-of-already" know about and find interesting. Although people visit museums to see and learn new things, because of their free-choice nature, most people selectively utilize these settings to build upon, reinforce and strengthen their own preferred, pre-existing science understandings. This does not mean that museums do not regularly support "new" learning. Visitors learn new things, particularly within structured encounters, such as school field-trips (e.g., Behrendt \& Franklin, 2014; Renner, 2011).

Research on the impacts of science learning from organized programs, in particular, family-focused efforts, suggests that these programs are extremely effective when integrated with trusted community-based organizations that share a common goal of supporting families, youth and communities (Ellenbogen, Luke, \& Dierking, 2007). This is particularly the case in terms of families that do not historically use museums to meet their freechoice learning needs. Research also demonstrates that the quality of interactions with those outside one's social group, e.g., museum explainers, guides, or even other visitors, influences learning (e.g., Gutwill \& Allen, 2010; Pattison, Gutwill, Auster, \& Cannady, 2019; Rosenthal \& Blankman-Hetrick, 2002).

Another increasingly critical "venue" in which to study free-choice science learning is media, broadly writ (cf., Jamieson, Kahan, \& Scheufele, 2017). It has long been assumed that mass media, particularly news, plays an important role in informal learning. Several recent studies have attempted to determine the direct influence of news media on science-related learning (American Academy of Arts and Sciences, 2019; Jamieson et al., 2017; National Science Board, 2019). Collectively, these studies demonstrate that traditional news represents a key source of adult information about science, even though many social scientists, and an increasing number of citizens, question the reliability of the information.

Television stands out as the main source of science information for Americans, Europeans and Asians (e.g., American Academy of Arts and Sciences, 2018; Huang, 2016; Jamieson et al., 2017; National Science Board, 2019). The Internet is a close second for audiences seeking general science and technology information, and the primary source for those interested in specific science issues (AAAS, 2019; Jamieson et al., 2017; Pew, 2006).
These investigations reinforce the generally held assumption that mass media can and does influence learning, although impacts are typically modest and idiosyncratic. The power of new digital media seems to be the agency they afford learners to directly answer personal science questions and/or fulfil curiosities. In this regard, the Internet has revolutionized what, where, how, when, why and with whom the public accesses information. Although initial digital media research disproportionately focused on usability issues, such as navigation, the work is now nuanced and learningfocused. For example, research demonstrates that the Internet is a dominant way that people get answers to health-related issues, with more than a third of all U.S. individuals doing so (Fox \& Duggan, 2013).

Arguably the fastest growing area of media-related freechoice science learning research is in the area of digital games, mirroring the growth in popularity of online and personal device video games over the past decade. The number of gamers worldwide has been estimated as approximately a billion individuals (No Author, 2018), and there are no signs of this number decreasing soon. Although the vast majority of games played have little science content, researchers argue that games support a range of science-relevant skills and capabilities, including visual short-term memory (Boot, Kramer, Simons, Fabiani, \& Gratton, 2008), spatial cognition (Feng, Spence, \& Pratt, 2007) and probabilistic inferences (Green, Pouget, \& Bavelier, 2010; see also, NRC, 2011). Meanwhile, some researchers believe that the "gamification" of education has the potential to dramatically change the way science is learned, primarily in school, and have some evidence of the potential of games for science learning (cf., Morris, Croker, Zimmerman, Gill, \& Romig, 2013).

Another major body of research has related to public science literacy, which as defined by Kirshenbaum (2009) is the ability of a person to "ask, find, or determine answers to questions derived from curiosity about everyday experiences." Several recent reviews by the American Academy of Arts \& Sciences (AAAS, 2018, 2019) and National Academies of Science (NRC, 2017) provide an excellent overview of the current state of affairs within the U.S., and recent comparisons between the U.S. and worldwide data suggest similar dynamics are at work (NSB, 2019). As summarized in the NRC report, although science and technology are embedded in virtually every aspect of modern life, and the public seems eager to become informed about science, communicating science effectively turns out to be a highly complex task. A common thread in both of these reports is a growing appreciation that the most widely held, and simplest model of what audiences "need" from science communicators" perspective, referred to as the "deficit model," is fundamentally flawed. The most effective 
approaches depend upon the specific needs, interests, circumstances and prior understandings and beliefs of the audience.

Although individuals may be highly informed about a particular science topic, their beliefs and social networks may mean they act in ways contrary to accepted scientific practice (Drummond \& Fischhoff, 2017). For example, this has been found true of individuals who deny such accepted science findings as climate change (e.g., Dunlap \& McCright, 2010) and evolution (e.g., MacFadden et al., 2007; National Academy of Sciences, 1999). As a consequence, when justifying their actions, individuals are likely to choose a level of explanation which meets their needs and beliefs, rather than necessarily scientific orthodoxy (cf., Drummond \& Fischhoff, 2017). Important to note though, is that ultimately science learning is a natural and common outcome of living within a science-rich world, situated within activities of everyday life (cf. Roth \& Calabrese Barton, 2004), and that people typically are eager to learn and act upon those things that directly support their personal needs and well-being (Falk, 2018). From this perspective, each individual in a community is likely to have a different science knowledge repertoire; a level of science understanding determined by his specific needs, abilities, and socio-historical context. These understandings and interests may or may not track with standard academic disciplines, often being much more situated with specific interdisciplinary topic areas such as gardening or rocketry. From this perspective, public understanding of science is not some generalized body of knowledge and skills that every person should have by a certain age, but rather a series of specific sets of only moderately overlapping knowledge and abilities that individuals construct over their lifetime. Thus, individuals possessing comparable science understandings would best be predicted by convergences in life experiences, professions, hobbies and interests, rather than convergences in formal education.

This view of science literacy also supports another growth area in both free-choice science practice and research - variously referred to as citizen or community science (cf., Bonney et al., 2009; Edwards, 2015; Science Europe, 2018); or engaged science learning (cf., McCallie et al., 2008). Often published in interdisciplinary science journals such as Science and Nature as well as disciplinary journals such as and Bioscience, Frontiers of Ecology and the Environment and Journal of Physics, this research documents and describes how, and to what degree, active engagement in scientific practices by nonprofessional scientists leads to science understanding, interest and identity, with the evidence indicating that by and large, such transformations do occur. The key appears to be the free-choice nature of the experience, the ability for individuals to ask and answer important scientific questions, often revolving around local or regional issues, that they themselves find interesting and worthwhile (cf., Bonney, Cooper, \& Ballard, 2016).

\section{Free-choice science education practice}

Not only are free-choice learning opportunities varied and expanding rapidly worldwide, so are the number of individuals engaged in facilitating such learning. A consequence of taking a broad-based approach to science education is that one begins to notice science teaching and learning in novel places (like cafes and pubs) or being put to use in profound ways. We estimate that worldwide, more than a half billion individuals are free-choice science educators; exceeding by roughly an order of magnitude the number of educators working in the formal sector. Given the rapid expansion of free-choice learning resources in Asia, within the next decade, the majority of free-choice science learning educators are likely to be based in this part of the world. In fact, so vast and diverse is this army of free-choice educators that clear definitions of what it actually means to be a free-choice science educator are challenging, perhaps impossible.

Educational practice in this sector takes every imaginable educational form, some of which is unique to a particular educational venue, e.g., exhibition design or program development in a museum, but more often, approaches are eclectic and situation-specific. In formal education, there is a long history of describing the skills and experience of a school educator; these definitions are reinforced by long-established, strictly regulated government credentialing. As a consequence, defining who is, and who is not a credentialed school teacher, is relatively easy. In the free-choice education realm, educators are not credentialed, certainly for the most part, not in education.

For example, in the U.S. there are tens of thousands of professional Extension Agents who for generations have worked as free-choice science educators, helping to insure that local farmers, fishers and the general public learn about the most recent advances in horticulture, dairying and aquaculture. Nearly all of these individuals have extensive training in the sciences; few if any have specific training in education. Every year roughly a billion people engage in science learning experiences at science centers, zoos, aquariums, parks, nature centers, botanical gardens, children's museums and natural history museums, all of which are created and supported by about 10 million or more staff and volunteers worldwide. As with Extension Agents, a large percentage of the creators and facilitators of these free-choice learning experiences have backgrounds in science, but only a small percentage have any explicit training or credentials in education.

Meanwhile in the "wild west" environment of digital media, thousands of new science-related websites, blogs, 
podcasts and videos are created every day with only the tiniest fraction of the developers of these resources having any professional training in education. Although some might argue that this is a problem with the practice of free-choice science learning, the reality is that it rarely appears to be problematic. At least in the U.S., although the relative contribution of schooling to the learning of science has steadily diminished over the past couple of decades, supplanted by an ever-increasing dependence upon free-choice learning resources (AAAS, 2019; Falk \& Needham, 2013), measures of public understanding of science among U.S. adults suggest science understanding, though not great, is higher than most nations and has remained relatively stable, or if anything slightly improved in recent years (NSB, 2019). This despite data that suggests that the U.S. regularly trails many nations on PISA scores and other tests of school-focused science knowledge, with relative performance actually declining over the past decades. Data such as these add to the doubts about the long-held assumption that the general public's long-term science beliefs, interests and knowledge are strongly dependent upon the quality of prior school experiences.

\section{Challenges for free-choice learning practitioners and researchers}

A major challenge for both free-choice learning practitioners and researchers is a lack of awareness and appreciation for the importance of these forms of learning, and a consequent lack of public funding to support the infrastructure of practice and research efforts. As a result, many free-choice learning venues are supported by entry fees that are exceedingly costly, as well as feebased offerings, such as afterschool or summer camp programs. Lack of funding in this arena is particularly detrimental to children and their families living in under-resourced communities. Evidence shows that in addition to the quality of the schools they attend, the greatest disparities in science learning among children and youth are linked to out-of-school opportunities. By the time they reach sixth grade, middle class youth have typically had 6000 more hours learning than students born into poverty (Wimer et al., 2006). Much of this learning relates to access to quality out-of-school experiences (cf., Archer, Dawson, Seakins, \& Wong, 2016; Dawson, 2017; Falk \& Dierking, 2010).

Another challenge area for the practice of free-choice learning was alluded to earlier, the lack of appropriate preparation for educators who work in this arena, and the lack of recognition they receive. In the twenty-first century, free-choice learning institutions are assuming ever more prominent roles in the public's science education, but the facilitators of free-choice science learning are often not classroom teachers. There is a vast network of graduate level science education programs, but these almost exclusively focus on classroom teaching. If an educator plans to work outside of the classroom, these programs are often of limited value.

Most free-choice learning educators are nontraditional teachers and mentors, such as after-school youth leaders, professional and amateur scientists, museum educators, educational web developers and parents. Designing appropriate preparation options for this varied group of educators is no small feat. Educators in this sector require expertise in teaching science in different ways and configurations than classroom teachers, and require information about learners of all ages. The value of free-choice educators has long been underappreciated. Characteristically, most free-choice science educators work 12 months, as opposed to 9 months, earn less annually than their counterparts in classrooms, receive more modest benefit packages, if at all, and have less job security (e.g., Bureau of Labor Statistics, U.S. Department of Labor, 2011a, 2011b).

\section{Future directions}

Current realities demand that we take on the challenge of envisioning and creating a lifelong science learning system that supports the needs of all learners; one that can support learning whatever, wherever and whenever that learning is required. This system must be designed to support the lifelong science learning of citizens of all ages, backgrounds and stations of life, recognizing the myriad places and ways in which people can engage and participate in science learning, as well as the many topical interests and reasons they may choose to engage and participate. Most importantly, its design must recognize that what is most important is to create opportunities for diverse learners to construct a robust science identity, one that meets their needs and makes sense to them in their everyday lives, be they a scientist, a technician, someone who engages in science-related hobbies and pursuits or a person with other types of expertise and interests, but whom we hope will have some basic understanding of science in order to lead a healthy life and make sound decisions based on evidence.

This is not a task that can be exclusively accomplished through formal education. No amount of redesign of schools and curriculum, or improvements in pre- and in-service professional development teacher training will be sufficient to accomplishing this task. As more and more science learning happens beyond the classroom, enacting meaningful science education reform is a challenge that transcends formal education. Free-choice learning is an essential, in fact arguably the predominant mode of lifelong science learning now and in the future. To not understand and embrace this form of learning as an essential component of the public's science education. 
is to seriously impede societies' ability to enhance public science learning.

To do this well, we must understand how to more effectively connect science learning opportunities across settings and the life span by working with educational colleagues in the myriad science settings in which science learning occurs. If we understand the connections and interrelationships that learners make within this lifelong science learning network, and work collaboratively with learners and colleagues engaged in science education across settings and the lifespan, we are far more likely to be able to build a system that better leverages and contributes to lifelong science engagement and learning.

Given how limited our current understanding of lifelong science learning is, coupled with the rapidly changing social, cultural and economic landscape of the twenty-first century, with great humility we offer the following initial ideas for where future lines of research could proceed. We envision two broad lines of focus. The first is a top-down view that attempts to deeply understand the structure and functioning of existing, as well as potential interrelationships between actors and agents in the broader learning landscape. The second is a bottom-up view that begins with the needs and interests of individual learners and attempts to deeply understand the ecology of learning for life from a learner-centered perspective. Both of these lines of inquiry will require teams from multiple disciplines and will be more robust if they involve both researchers and practitioners and occur across extended time frames (at least 5-10 years).

\section{Future research directions: the learning ecosystem}

As the nature of science learning continues to expand beyond the confines of formal schooling, rapidly becoming 24/7 and lifelong, the need for a more expansive and holistic understanding and approach to science learning is required. As outlined above, today's science education opportunities include not only traditional schooling, but also libraries, museums, zoos, aquaria, science centers, parks and preserves; diverse broadcast media such as television, podcasts, film; organized youth and adult programs after-school and after work, weekends during vacation time; special-interest clubs and hobby groups on every imaginable topic; and, an ever-increasing array of digital media such as personal games, the Internet, podcasts and social media.

Although it is not a large conceptual leap to envision a complex science education ecosystem that supports and facilitates science learning, it is quite another thing to understand how it actually functions on the ground for learners. We know some kind of basic infrastructure for supporting science learning already exists in virtually every community. We also know that increasingly the institutional constituents of the ecosystem, e.g., schools, universities, libraries and museums, are being supplanted by non-institutional, more fluid entities, such as hobby groups and social networks, both virtual and physical. Yet currently, we know precious little about how this complicated and highly intertwined ecosystem functions or how the various pieces intersect and interact.

Historically, investigations of science learning have been quite bounded. Most studies have investigated a single topic area, a specific age cohort, within classrooms, over the time frame of a unit, or at most a school year; most of this effort has been evaluation rather than research-focused. Investigations of free-choice learning also have historically been bounded, e.g., visitors to a specific museum, often a single exhibition, framed by the duration of a single visit. This, despite the growing appreciation that learning in general, and science learning in particular, is rarely instantaneous, often problemoriented, rather than discipline-focused, and virtually never occurs in one place at one time. Learning is always strongly socio-culturally framed and cumulative. In light of these realities we need to expand the scope and scale of investigations to better encompass the realities of lifelong science learning. We need to give greater emphasis to the adult years of science learning, including within the workplace, since this is not only where most people spend the majority of their lives, it is also the time when much science learning occurs.

Implementing this new way of conceptualizing the nature of science learning will require different methods, different questions and different types of financial investments. It also will require new partnerships between organizations and individuals-partnerships that better reflect the actual structure and functioning of what, where, when, why and how the public learns science.

\section{An ecology of individual learning for life}

Like the prevailing industrial economic models of the time, throughout the 19th and 20th centuries the focus of science learning research and practice was top-down with an emphasis on disciplines, instruction and curriculum. The organizing framework was that institutions could provide all that was necessary for an informed, science-literate citizenry. Nations and states set up school systems to cater to the learning needs defined by the society and specific institutions in the society, such as corporations and government entities; schooling was designed to satisfy these constituencies and insure that learners met specific requirements. Learners were expected to appreciate having these opportunities and to meet curricular demands in order to further their career development. While there is increasingly greater openness toward learner participation, and even 
individualization within most formal and even many informal education environments, the learner is still basically expected to accept the package for what it is. The learner is the consumer of a highly "engineered," ready-made or, at best, minimally customizable product.

This is not the reality of the twenty-first century. Learning, like economic innovation, is increasingly becoming bottom-up, controlled by the individual and highly focused on meeting personal needs and interests. This shift has tremendous implications for not only how learning experiences need to be designed and facilitated, but equally for how research on learning should be conducted. In the new world order, the learner's role is quite different. Although the reasons for learning may sometimes still be associated with the pursuit of formal learning objectives or career goals, as research cited in earlier in this chapter documents, the majority of science learning will be aimed at meeting individual learner's self-related interests and needs, unassociated with degrees and employment-science learning related to hobbies, personal curiosities, or individual needs such as broad inter-disciplinary topics such as neighborhood's environmental quality or responding to personal healthrelated issues.

Most science education research is still predicated on conceptualizations of learning that make sense within academic contexts - mastery of disciplinary-organized facts and concepts in order to orally or in writing describe and defend an idea or proposition. Within the world of free-choice learning, learning is primarily for personal fulfillment, disproportionately motivated by the needs of identity formation and reinforcement, and increasingly digital and visual. In this context, we need a more learner-centered approach to science education that places issues of learner motivation and identity at the center of inquiry. We suggest that future investigations of science learning situate the learner at the center, rather than the periphery of the learning process, as an active co-constructor, not merely a passive recipient. In order to meaningfully understand what science learning is, but even more importantly, why it happens, studies also should frame science learning within the larger ecological context of an individual's life and the learning landscape in which s/he participates.

\section{Conclusion}

We believe the ideas and findings presented in this paper support the necessity of reframing the practices and investigations of science learning to encompass the entire lifespan. We further believe that there needs to be an increasing appreciation that free-choice learning is not a mere nicety, some adjunct to the real science learning occurring within schools. Rather free-choice learning experiences actually form the core of the public's science learning. Thus, if we are to understand, let alone measurably improve the quality of public science education, the place to start will be through greater focus on and appreciation of free-choice learning and how it connects to schooling and workplace learning.

\section{Abbreviations \\ AAAS: American Academy of Arts \& Sciences; NAS: National Academies of Science; NRC: National Research Council; NSB: National Science Board}

\section{Acknowledgements}

There are no acknowledgements.

\section{Declarations}

All data and material used in the creation of this manuscript are available by contacting the authors.

\section{Authors' contributions}

The two authors equally contributed to the preparation of this manuscript. Both authors read and approved the final manuscript.

\section{Funding}

No external sources of funding were utilized in the preparation of this manuscript.

\section{Competing interests}

The authors declare that they have no competing interests.

Received: 15 April 2019 Accepted: 23 October 2019

Published online: 28 November 2019

\section{References}

American Academy of Arts \& Sciences (2018). Perceptions of science in America. Cambridge: American Academy of Arts \& Sciences.

American Academy of Arts \& Sciences (2019). Encountering science in America. Cambridge: American Academy of Arts \& Sciences.

Archer, L., Dawson, E., DeWitt, J., Seakins, A., \& Wong, B. (2015). "Science capital": A conceptual, methodological, and empirical argument for extending bourdieusian notions of capital beyond the arts. Journal of Research in Science Teaching, 52(7), 922-948.

Archer, L., Dawson, E., Seakins, A., \& Wong, B. (2016). Disorienting, fun or meaningful? Disadvantaged families' experiences of a science museum visit. Cultural Studies of Science Education, 11(4), 917-939.

Barab, S. A., \& Kirshner, D. (2001). Rethinking methodology in the learning sciences. Journal of the Learning Sciences, 10(1-2), 5-15.

Behrendt, M., \& Franklin, T. (2014). A review of research on school field trips and their value in education. International Journal of Environmental and Science Education, 9(3), 235-245.

Bonney, R., Ballard, H., Jordan, R., McCallie, E., Phillips, T., Shirk, J., \& Wilderman, C. C. (2009). Public participation in scientific research: Defining the field and assessing its potential for informal science education. A CAISE inquiry group report. Washington, DC: Center for Advancement of Informal Science Education (CAISE).

Bonney, R., Cooper, C., \& Ballard, H. (2016). The theory and practice of citizen science: Launching a new journal. Citizen Science: Theory and Practice, 1(1), 1-3.

Boot, W. R., Kramer, A. F., Simons, D. J., Fabiani, M., \& Gratton, G. (2008). The effects of video game playing on attention, memory, and executive control. Acta Psychologica, 129, 387-398.

Bureau of Labor Statistics, U.S. Department of Labor (2011a). Occupational outlook handbook, 2010-11 edition, archivists, curators, and museum technicians. Washington, DC: U.S. Government Printing Office.

Bureau of Labor Statistics, U.S. Department of Labor (2011b). Occupational outlook handbook, 2010-11 edition, teachers-kindergarten, elementary, middle, and secondary. Washington, DC: U.S. Government Printing Office.

Dawson, E. (2017). Social justice and out-of-school science learning: Exploring equity in science television, science clubs and maker spaces. Science Education, 101(4), 539-547. 
Diaz, J., Griffith, M., Ng, J., Reinert, S., Friedmann, P., \& Moulton, A. (2002). Patients use of the internet and clinical settings for medical information. Journal of General Internal Medicine, 17(3), 180-185.

Drummond, C., \& Fischhoff, B. (2017). Individuals with greater science literacy and education have more polarized beliefs on controversial science topics. Proceedings of the National Academies of Sciences, 114(36), 9587-9592.

Dunlap, R. E., \& McCright, A. M. (2010). Climate change denial: Sources, actors and strategies. In C. Lever-Tracy (Ed.), Routledge handbook of climate change and society, (pp. 240-259). Abingdon: Routledge.

Edwards, R. (2015). Enhancing informal learning through citizen science - Background literature. Center for Advancing Informal Science Education http://www. informalscience.org/sites/default/files/Enhancing_Informal_Learning_Through_ Citizen_Science_Review_PDF.pdf. Retrieved 28 Feb 2019.

Ellenbogen, K., Luke, J., \& Dierking, L. (2007). Family learning in museums: A perspective on a decade of research. In J. Falk, L. Dierking, \& S. Foutz (Eds.), In principle, in practice, (pp. 17-30). Lanham: AltaMira Press.

Falk, J. H. (2009). Identity and the museum visitor experience. Walnut Creek: Left Coast Press.

Falk, J. H. (2018). Born to choose: Evolution, self and well-being. London: Routledge

Falk, J. H., \& Dierking, L. D. (2010). The 95\% solution: School is not where most Americans learn most of their science. American Scientist, 98, 486-493.

Falk, J. H., Dierking, L. D., Osborne, J., Wenger, M., Dawson, E., \& Wong, B. (2015). Analyzing science education in the U.K.: Taking a system-wide approach. Science Education, 99(1), 145-173.

Falk, J. H., Dierking, L. D., Swanger, L., Staus, N., Back, M., Barriault, C., Verheyden, P. (2016). Correlating science center use with adult science literacy: An international, cross-institutional study. Science Education, 100(5), 849-876.

Falk, J. H., \& Needham, M. D. (2013). Factors contributing to adult knowledge of science and technology. Journal of Research in Science Teaching, 50(4), 431-452.

Falk, J. H., Pattison, S., Meier, D., Livingston, K., \& Bibas, D. (2018). The contribution of science-rich resources to public science interest. Journal of Research in Science Teaching, 55(3), 422-445.

Falk, J.H., Meier, D., Pattison, S., Livingston, K. \& Bibas, D. (2019). The contributions made by five science education resources to youth's interest in science. http:// www.instituteforlearninginnovation.org/wp-content/uploads/2019/10/R21.pdf

Feng, J., Spence, I., \& Pratt, J. (2007). Playing an action videogame reduces gender differences in spatial cognition. Psychological Science, 18, 850-855.

Fox, S., \& Duggan, M. (2013). Health online 2013. Pew Research Center: Internet and Technology http://www.pewinternet.org/2013/01/15/health-online-2013/ Retrieved 28 Feb 2019.

Green, C. S., Pouget, A., \& Bavelier, D. (2010). Improved probabilistic inference, as a general learning mechanism with action video games. Current Biology, 20, 1573-1579.

Gutwill, J., \& Allen, S. (2010). Group inquiry at science museum exhibits: Getting visitors to ask juicy questions. San Francisco: The Exploratorium.

Huang, C.-J. (2016). Public communication of science and technology in Taiwan In M. H. Chiu (Ed.), Science education research and practices in Taiwan, (pp. 279-297). Singapore: Springer.

Jamieson, K. H., Kahan, D., \& Scheufele, D. (Eds.) (2017). The Oxford handbook of the science of science communication. Oxford: Oxford University Press.

Kirshenbaum, S. (2009). What is scientific literacy? Discover Magazine http://blogs. discovermagazine.com/intersection/2009/03/17/what-is-scientific-literacy/ \#.XOhRc8R7nD4. Retrieved 24 May 2019.

MacFadden, B. J. Dunckel, B. A., Ellis, S., Abraham-Silver, L, Kisiel, J. \& Koke, J. (2007). Natural history museum visitors' understanding of evolution. Bioscience, 57(10), 875-882.

McCallie, E., Bell, L., Lohwater, T., Falk, J., Lehr, J. L., Lewenstein, B., Wiehe, B. (2008). Public engagement with science and informal science education. Washington, D.C.: Center for Informal Science Education (CAISE).

Morris, B. J., Croker, S., Zimmerman, C., Gill, D., \& Romig, C. (2013). Gaming science: The "gamification" of scientific thinking. Frontiers of Psychology, 4, 607-612.

National Academy of Sciences (1999). Science and creationism: A view from the National Academy of Sciences, (2nd ed., ). Washington, DC: National Academies Press

National Research Council (2009). Learning science in informal environments: People, places and pursuits. Washington, DC: National Academies Press.

National Research Council (2011). Learning science through computer games and simulations. Washington, DC: National Academies Press.
National Research Council (2015). Identifying and supporting productive STEM programs in out-of-school settings. Washington, DC: National Academies Press.

National Research Council (2016). Science literacy: Concepts, contexts, and consequences. Washington, DC: The National Academies Press.

National Research Council (2017). Communicating science effectively: A research agenda. Washington, DC: National Academies Press.

National Science Board (2019). Science and engineering indicators 2018. Arlington: National Science Foundation.

No Author. (2018). Gaming video content market - statistics \& facts. Statista.com https://www.statista.com/topics/3147/gaming-video-content-market/ Retrieved 28 Feb 2019.

Pattison, P., Gutwill, J., Auster, R., \& Cannady, M. (2019). Experimental and quasiexperimental designs in visitor studies: A critical reflection on three projects. Visitor Studies, 22(1), 43-66.

Pew (2006). The internet as a resource for news and information about science. Technical report. http://www.pewinternet.org/report_display.asp?r=191.

Phelan, S., Bauer, J., \& Lewalter, D. (2018). Visit motivations: Development of a short scale for comparison across sites. Museum Management and Curatorship, 33(1), 25-41.

Renner, N. O. (2011). Multisensory sensemaking: Children's exploratory behavior has organizing structure at micro- and macro-scales. In Paper presented at the annual meeting of Cognitive Science Society, Boston, Massachusetts, July 21, 2011.

Rosenthal, E., \& Blankman-Hetrick, J. (2002). Conversations across time: Family learning in a living history museum. In G. Leinhardt, K. Crowley, \& K. Knutson (Eds.), Learning conversations in museums, (pp. 305-329). Mahwah: Lawrence Erlbaum Associates.

Roth, W.-M., \& Calabrese Barton, A. (2004). Rethinking scientific literacy. New York: Routledge Falmer.

Science Europe. (2018). Science Europe briefing paper: Citizen Science. https:// www.scienceeurope.org/wp-content/uploads/2018/07/SE_BriefingPaper_ CitizenScience.pdf. Retrieved 24 May 2019

Shein, P. P., Falk, J. H., \& Li, Y.-Y. (2019). The role of science identity in science center visits and effects. Science Education, 103(6), 1478-1492.

Sheng, C.-W., \& Chen, M.-C. (2012). A study of experience expectations of museum visitors. Tourism Management, 33, 53-60.

Vedder-Weiss, D. (2016). Serendipitous science engagement: A family selfethnography. Journal of Research in Science Teaching, 54, 350-378.

Wimer, C., Bouffard, S. M., Caronongan, P., Dearing, E., Simpkins, S., Little, P., \& Weiss, H. (2006). What are kids getting into these days?: Demographic differences in youth out-of school time participation. Cambridge: Harvard Family Research Project.

\section{Publisher's Note}

Springer Nature remains neutral with regard to jurisdictional claims in published maps and institutional affiliations.

\section{Submit your manuscript to a SpringerOpen ${ }^{\odot}$ journal and benefit from:}

- Convenient online submission

- Rigorous peer review

- Open access: articles freely available online

- High visibility within the field

- Retaining the copyright to your article

Submit your next manuscript at $>$ springeropen.com 